\title{
STRATEGI PENGEMBANGAN BUDIDAYA LEBAH MADU DI KELURAHAN KALAMPANGAN KECAMATAN SABANGAU KOTA PALANGKA RAYA
}

\author{
HONEY CULTIVATION DEVELOPMENT STRATEGY \\ IN KALAMPANGAN VILLAGE SABANGAU SUBDISTRICT \\ PALANGKA RAYA CITY
}

\author{
${ }^{1}$ Yunita, ${ }^{2}$ Pordamantra, ${ }^{3}$ Berkat A. P.
}

\begin{abstract}
${ }^{1}$ Alumnus Program Studi Agribisnis Fakultas Pertanian Universitas Palangka Raya
${ }^{2,3}$ Staf Pengajar Program Studi Agribisnis Fakultas Pertanian Universitas Palangka Raya email: pordamantra@gmail.com
\end{abstract}

\begin{abstract}
ABSTRAK
Penelitian ini dilakukan untuk: (1). Mengidentifikasi faktor internal dan eksternal yang menjadi kekuatan, kelemahan, peluang dan ancaman dengan metode analisis IFAS dan EFAS; (2). Merumuskan alternatif strategi yang memungkinkan untuk diterapkan dengan matriks SWOT. Hasil penelitian menunjukkan bahwa: (1). Faktor-faktor internal (kekuatan dan kelemahan) dan eksternal (peluang dan ancaman) pengembangan budidaya lebah madu di Kelurahan Kalampangan yaitu kekuatan memiliki empat variable antara lain tenaga kerja mengikuti pelatihan, ketersediaan sarana produksi, manajemen budidaya telah diterapkan dan rantai pemasaran pendek. Kelemahan memiliki dua variabel, antara lain kurangnya keikutsertaan anggota kelompok dan kemasan produk yang sederhana. Peluang memiliki tiga variabel, yaitu adanya perhatian Pemerintah Daerah, menjalin hubungan kemitraan dan perkembangan teknologi dan informasi. Sedangkan ancaman memiliki tiga variabel, antara lain harga produk madu bersaing, perubahan cuaca dan serangan hama, (2). Alternatif strategi yang dapat diterapkan dalam upaya pengembangan budidaya lebah madu di Kelurahan Kalampangan adalah strategi (SO) yaitu memanfaatkan dukungan Pemeritah Daerah dalam memperluas jaringan pemasaran produk, dan mengembangkan teknologi budidaya lebah madu; strategi (WO) yaitu mengadakan pelatihan dan pendampingan untuk meningkatkan keterampilan petemak dan memperbaiki kemasan produk; strategi (ST) yaitu mempertahankan produksi dan menjaga kualitas produk; strategi (WT) yaitu mempertahankan kerjasama kelompok dan menjaga luasan areal tanaman pakan.
\end{abstract}

Kata kunci: Budidaya lebah madu, strategi, SWOT

\begin{abstract}
This research is done (1). to identify about the internal and external factors which become the strength, weakness, opportunity, threat by analysis method of IFAS and EFAS; (2). to formulate the alternative strategy that being possible to be applied by SWOT matrix. The results of this research show that (1). internal factors (strengths and weaknesses) and external (opportunities and threats) the development of honey bee cultivation in the Kalampangan Village, that is strength has four variables, among others workforce training, production facilities are available, cultivation management has been implemented and the marketing chain is short. Weakness has two variables, among others lack of group members participation and less attractive product packaging. Opportunities have three variables, that
\end{abstract}


is the government's attention, establishing partnership relations and technological and information development. While threats have three variables, among others competitively priced honey products, weather changes and pest attacks. (2). the alternative strategy which can be applied for the effort of developing honey bee cultivation in the urban village of Kalampangan is the (SO) strategy which means to use the government's support on spreading product marketing network, and developing cultivation technology of honey bee; the (WO) strategy which means we make a training and associating to improve the skills of the breeder and repairing the product's packaging; the (ST) strategy which means to maintain the production, and maintain the product's quality; and the (WT) strategy which means to maintain the group cooperation and to keep the area of woof plants.

Keywords: Honey bee cultivation, strategy, SWOT matrix

\section{PENDAHULUAN}

\section{Latar Belakang}

Perlebahan memiliki peranan penting di dalam strategi pembangunan ekonomi masyarakat pedesaan dan sektor pertanian berkelanjutan. Kegiatan perlebahan menghasilkan produk pangan berkualitas yang dapat membantu meningkatkan gizi dan penghasilan masyarakat perdesaan. Melalui fungsi penyerbukan, lebah madu juga berperan besar dalam meningkatkan produksi buah dan biji serta menjaga kelangsungan hidup dan karagaman jenis tumbuhan. Pada banyak negara, budidaya lebah madu telah berkembang menjadi kegiatan usaha berskala besar. Budidaya lebah madu adalah salah satu kegiatan usaha yang tidak berbasis lahan, sehingga tidak menjadi pesaing bagi usaha pertanian pada umumnya. Perlebahan bahkan berperan dalam optimalisasi sumberdaya alam melalui pemanfaatan nektar dan serbuk sari, yakni dua produk tumbuhan yang sebagian besar akan terbuang sia-sia apabila tidak dimanfaatkan untuk pakan lebah madu (Kuntadi, 2010).

Lebah madu termasuk dalam kelas insekta yaitu jenis serangga dengan spesiesnya yang beragam. Spesies lebah yang berada di wilayah Indonesia diantaranya jenis cerana, dorsata, florea dan mellifera. Dari lebah-lebah tersebut yang sering dibudidayakan karena mampu menghasilkan madu kualitas unggulan adalah jenis mellifera.
Usaha budidaya lebah madu sangat potensial untuk dikembangkan di Kota Palangka Raya, mengingat sumber daya alamnya sangat mendukung dan memenuhi berbagai persyaratan lokasi untuk budidaya lebah madu. Oleh karena itu dibutuhkan suatu manajemen strategi yang baik dalam selama proses perkembangan budidaya lebah madu. manajemen strategis adalah serangkaian keputusan dan tindakan manajerial yang menentukan kinerja perusahaan dalam jangka panjang. Termasuk di dalamnya pengamatan lingkungan (eksternal maupun internal), perumusan strategi (perencanaan jangka panjang), implementasi strategi, evaluasi, serta pengendalian. Bidang ilmu manajemen strategis menekankan pada pengamatan dan evaluasi peluang (opportunities) dan ancaman (threats) lingkungan dengan melihat kekuatan (strengths) dan kelemahan (weaknesses) perusahaan (Setiawan, 2011). Menurut Basia, L et al. (2016), Pengertian strategi dibedakan ke dalam pengertian umum dan pengertian khusus. Pengertian umum strategi adalah proses penentuan rencana para pemimpin puncak yang berfokus pada tujuan jangka panjang organisasi, disertai penyusunan suatu cara atau upaya bagaimana agar tujuan tersebut dapat dicapai. Pengertian khusus strategi adalah tindakan yang bersifat inkremental (meningkat) dan terus-menerus, serta dilakukan berdasarkan sudut pandang tentang apa yang diharapkan oleh para pelanggan di masa depan. 
Salah satu kelurahan di Kota Palangka Raya yang telah melakukan usaha budidaya lebah madu, yaitu Kelurahan Kalampangan, Kecamatan Sabangau. Kelurahan Kalampangan merupakan salah satu daerah yang telah membudidayakan lebah madu. Para peternak yang melakukan kegiatan budidaya terlebih dahulu mengikuti pelatihan yang diadakan oleh Dinas Kehutanan Provinsi Kalimantan Tengah. Jenis lebah madu yang dibudidayakan oleh kelompok petani di Kalampangan adalah jenis lebah madu Apis mellifera. Salah satu alasan petani membudidayakan lebah madu jenis ini adalah karena produksi madunya yang sangat tinggi jika dibandingkan dengan jenis lebah madu yang lain. Budidaya lebah madu memiliki kelebihan yaitu dapat membantu proses penyerbukan pada tanaman. Pemilihan lokasi budidaya lebah madu sangat penting karena dapat mempengaruhi hasil produksi lebah madu tersebut. Selain pemilihan lokasi, hal yang harus diperhatikan oleh peternak di Kalampangan adalah ketersediaan pakan lebah madu yang cukup agar lebah madu tidak perlu terbang terlalu jauh dari sarangnya untuk mencari makan.

\section{Tujuan Penelitian}

Penelitian ini bertujuan untuk: 1 . Mengidentifikasi faktor-faktor internal dan eksternal yang mempengaruhi pengembangan budidaya lebah madu di Kelurahan Kalampangan, Kecamatan Sabangau, Kota Palangka Raya; dan 2. Merumuskan alternatif strategi yang memungkinkan untuk diterapkan dalam pengembangan budidaya lebah madu di Kelurahan Kalampangan, Kecamatan Sabangau, Kota Palangka Raya.

\section{METODE PENELITIAN}

Penelitian ini dilaksanakan di Kelurahan Kalampangan, Kecamatan Sabangau, Kota Palangka Raya. Penentuan lokasi penelitian dilakukan secara sengaja (purposive) dengan pertimbangan
Kelurahan Kalampangan termasuk dalam salah satu kelompok tani hutan lebah madu yang ada di Kota Palangka Raya.

Populasi dalam penelitian ini adalah peternak lebah madu yang ada di Kelurahan Kalampangan. Penentuan sampel dilakukan secara purposive sampling. Menurut Sugiyono (2013), purposive sampling yaitu teknik untuk menentukan sampel penelitian dengan beberapa pertimbangan tertentu. Sampel yang menjadi informan dalam penelitian ini ditentukan dengan pertimbangan sampel yang digunakan adalah orang yang terlibat langsung dalam kegiatan budidaya lebah madu dan mengetahui tentang permasalahan yang dihadapi dalam kegiatan budidaya lebah madu. Berdasarkan pertimbangan tersebut sampel yang digunakan adalah:

1. Bapak Budiyana sebagai Ketua Kelompok Tani Hutan Lima Bersaudara.

2. Bapak Sauji sebagai Ketua Kelompok Tani Hutan Wana Lestari 2.

3. Bapak Surono sebagai Penyuluh Kehutanan Madya dari Dinas Kehutanan Provinsi Kalimantan Tengah.

Data yang digunakan dalam penelitian ini adalah data primer dan data sekunder. Data primer diperoleh melalui pengamatan langsung di lapangan dan melalui wawancara secara langsung dengan peternak lebah madu dan penyuluh menggunakan daftar pertanyaan (kuesioner) yang mencakup identitas responden, karakteristik dan variabelvariabel yang menjadi faktor internal dan eksternal pada usaha lebah madu. Adapun data sekunder merupakan data yang diperoleh dari instansi atau lembaga yang terkait seperti Badan Pusat Statistik dan Kantor Kelurahan Kalampangan.

Dalam penelitian ini analisis yang akan digunakan yaitu analisis deskriptif, dan analisis strategi dengan menggunakan analisis faktor internal atau Internal Strategic Factors Analysis Summary (IFAS), analisis faktor eksternal atau 
External Strategic Factor Analysis Summary (EFAS), dan analisis SWOT (matrik SWOT). Analisis SWOT digambarkan dalam matrik SWOT dengan 4 kemungkinan alternatif strategi, yaitu strategi kekuatan-peluang ( $\mathrm{S}$-O strategies), strategi kelemahan-peluang ( $W$ - $O$ strategies), strategi kekuatan-ancaman ( $S$ $T$ strategies), dan strategi kelemahanancaman ( $W$-T strategies).

\section{HASIL DAN PEMBAHASAN}

Identifikasi Faktor-Faktor Internal dan
Eksternal Pengembangan
Lebah Madidaya
Kalampangan di
Kelurahan
Strategi pengembangan dalam budidaya lebah madu dengan menggunakan analisis SWOT, yaitu dengan cara mengidentifikasi faktor-faktor internal dan eksternal yang mempengaruhi pengembangan budidaya lebah madu. Faktor internal dan eksternal dalam budidaya lebah madu di Kelurahan Kalampangan dapat dilihat berdasarkan Tabel 1 berikut.

Tabel 1. Kekuatan dan Kelemahan Dalam Pengembangan Budidaya Lebah Madu di Kelurahan Kalampangan

\begin{tabular}{|c|c|c|}
\hline $\begin{array}{l}\text { Faktor Strategi } \\
\text { Internal }\end{array}$ & Kekuatan & Kelemahan \\
\hline Tenaga kerja & 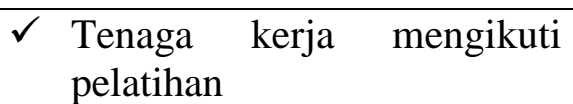 & $\begin{array}{ll}\checkmark & \text { Kurangnya keikutsertaan } \\
& \text { anggota kelompok }\end{array}$ \\
\hline Produksi & $\begin{array}{ll}\checkmark & \text { Ketersediaan sarana } \\
& \text { produksi } \\
\checkmark & \text { Manajemen budidaya telah } \\
\text { diterapkan }\end{array}$ & \\
\hline Pemasaran & $\checkmark \quad$ Rantai pemasaran pendek & $\begin{array}{ll}\checkmark & \text { Kemasan } \\
\text { sederhana }\end{array}$ \\
\hline
\end{tabular}

Sumber: Data primer diolah, 2019.

\section{Kekuatan (Strenghts)}

1. Tenaga kerja mengikuti pelatihan

Tenaga kerja yang digunakan dalam kegiatan budidaya lebah madu di Kelurahan Kalampangan berbeda-beda tergantung kelompok tani masing-masing. Tenaga kerja yang bekerja pada KTH Lima Bersaudara berjumlah 5 orang dan mereka telah mengikuti pelatihan. Pelatihan yang diikuti yaitu pelatihan dari peternak yang ada di Semarang dan pelatihan yang diadakan oleh Dinas Kehutanan Provinsi Kalimantan Tengah. Sementara untuk KTH Wana Lestari 2, tenaga kerja yang bekerja berjumlah 2 orang semuanya telah mengikuti pelatihan yang diadakan oleh Dinas Kehutanan Provinsi Kalimantan Tengah. Bentuk pelatihan yang diberikan oleh Dinas Kehutanan Provinsi Kalimantan Tengah adalah pelatihan tentang cara budidaya lebah madu yang baik agar dapat menghasilkan produksi yang maksimal.

2. Ketersediaan sarana produksi

Peternak lebah madu di Kelurahan Kalampangan baik untuk KTH Lima Bersaudara dan KTH Wana Lestari 2 memanfaatkan lahan kosong disekitar tempat tinggalnya untuk kegiatan budidaya lebah madu. Lahan kosong tersebut digunakan untuk meletakkan kotak/stup koloni lebah madu. Penggunaan lahan kosong disekitar tempat tinggalnya dimaksudkan agar peternak lebih mudah untuk merawat dan memudahkan peternak selama proses produksi lebah madu, pemeliharaan lebah madu sampai 
pemanenan. Selain lahan untuk budidaya lebah madu, sarana produksi lainnya adalah ketersediaan bibit lebah madu. Untuk bibit lebah madu, peternak bisa membelinya pada KTH Lima Bersaudara, karena KTH Lima Bersaudara sudah bisa mengembangkan bibit lebah madu dan membuat lebah ratu sendiri. Untuk pakan lebah madu, para peternak di Kelurahan Kalampangan baik KTH Lima Bersaudara atau KTH Wana Lestari 2 mereka menanam tanaman yang menghasilkan bunga disekitar tempat tinggalnya, hal ini dimaksudkan agar lebah madu tidak perlu terbang jauh untuk mencari pakannya. Sedangkan untuk peralatan yang digunakan selama kegiatan budidaya lebah madu tersedia untuk masing-masing kelompok peternak baik peralatan utama, peralatan pelengkap dan peralatan petugas.

3. Manajemen budidaya telah diterapkan

Peternak lebah madu di Kelurahan Kalampangan melakukan kegiatan manajemen, yaitu pada proses perencanaan jenis lebah madu yang akan dibudidayakan. Perencanaan tenaga kerja yang digunakan dalam kegiatan budidaya lebah madu. Kegiatan pengorganisasian terdapat dua indikator yang perlu dilihat, yaitu pembagian tugas kepada masingmasing tenaga kerja dan pengkoordinasian antar tenaga kerja dalam kegiatan produksi. Pada variabel pengarahan, ketua kelompok melakukan pengarahan kepada tenaga kerja untuk melakukan tugasnya sesuai dengan bidang masing-masing. Kegiatan pengawasan para peternak di Kelurahan Kalampangan, meliputi: (a) pemeliharaan, kontrol hama dan penyakit pada lebah madu; (b) Stimulasi pakan. Stimulasi pakan adalah pakan tambahan yang diberikan pada lebah madu jika tanaman pakan sedang tidak berbunga atau musim panceklik dan saat sedang musim hujan. Cairan stimulan berasal dari campuran air dan gula dengan perbandingan $1: 1$.

4. Rantai pemasaran pendek

Rantai pemasaran untuk peternak KTH Wana Lestari 2, rata-rata konsumen yang membeli produk madu pada kelompok ini adalah untuk dikonsumsi sendiri. Sementara untuk KTH Lima Bersaudara, selain menjual ke konsumennya langsung kelompok tani ini juga menitipkan produk madunya pada toko obat Gayuh Husada, Warung Pincoek, KPD Swalayan dan Hypermart di Kota Palangka Raya.

\section{Kelemahan (Weaknesses)}

1. Kurangnya keikutsertaan anggota kelompok.

KTH Lima Bersaudara memiliki jumlah anggota kelompok sebanyak 15 orang dimana semua anggota kelompoknya pernah mengikuti pelatihan, baik yang diadakan oleh Dinas Kehutanan Provinsi Kalimantan Tengah maupun yang dilakukan oleh Bapak Budiyana selaku ketua kelompok. Akan tetapi, dalam kegiatan produksi hanya terdapat 5 anggota yang berperan dalam kegiatan produksi budidaya lebah madu. Hal ini dikarenakan 10 orang anggota lain yang tidak berpartisipasi dalam kegiatan budidaya lebah madu lebih fokus pada pekerjaan utama mereka. Sedangkan untuk KTH Wana Lestari 2, memiliki anggota kelompok berjumlah 10 orang dan hanya 2 orang saja yang terlibat dalam kegiatan produksi budidaya lebah madu. Kurangnya keikutsertaan anggota kelompok karena anggota kelompok ini memiliki pekerjaan utama lain yaitu sebagai petani dan kegiatan budidaya lebah madu hanya dijadikan sebagai pekerjaan sampingan mereka.

2. Kemasan produk yang sederhana

Kemasan produk madu KTH Wana Lestari 2 masih sederhana, karena kemasan yang digunakan adalah kemasan botol plastik biasa dengan ukuran $100 \mathrm{ml}$ sampai $500 \mathrm{ml}$ yang dibeli di pasar. Dalam kemasannya tidak terdapat merk dagang, label halal dan persyaratan lain yang biasanya dimiliki oleh kemasan produk madu lainnya. Hal ini mengakibatkan produk madu kelompok ini tidak bisa dijual ke swalayan, toko obat atau apotik 
karena kemasannya yang dinilai kurang menarik dan masih sederhana.

Untuk mengetahui faktor eksternal

yang mempengaruhi pengembangan budidaya lebah madu di Kelurahan Kalampangan, dapat dilihat pada Tabel 2.

Tabel 2. Peluang dan Ancaman dalam Pengembangan Budidaya Lebah Madu di Kelurahan Kalampangan

\begin{tabular}{lll}
\hline \multicolumn{1}{c}{$\begin{array}{c}\text { Faktor Strategi } \\
\text { Eksternal }\end{array}$} & \multicolumn{1}{c}{ Peluang } & Ancaman \\
\hline Pemerintah & $\checkmark$ & $\begin{array}{l}\text { Adanya perhatian } \\
\text { pemerintah (O1) }\end{array}$ \\
\hline Pesaing & $\checkmark \begin{array}{l}\text { Menjalin hubungan } \\
\text { kemitraan (O2) }\end{array}$ & $\checkmark \quad \begin{array}{l}\text { Harga produk madu } \\
\text { bersaing (T1) }\end{array}$ \\
\hline Teknologi & $\checkmark \begin{array}{l}\text { Perkembangan teknologi } \\
\text { dan informasi (O3) }\end{array}$ & \\
\hline Lingkungan & & $\checkmark$ Perubahan cuaca (T2) \\
\hline
\end{tabular}

Sumber: Data primer diolah, 2019.

\section{Peluang (Opportunities)}

1. Adanya perhatian Pemerintah

Menurut pak Surono, selaku penyuluh kehutanan madya, pemerintah daerah khususnya Dinas Kehutanan Provinsi Kalimantan Tengah memiliki peran penting dalam keberlangsungan KTH lebah madu yang ada di Kota Palangka Raya. Salah satu peran pemerintah yaitu dengan memberikan bantuan, berupa bantuan dana, pelatihan, informasi pasar serta melakukan monitoring terhadap kelompok tani hutan yang ada di Kalampangan. Selain bantuan, pemerintah juga melakukan programprogram yang terkait dengan budidaya lebah madu, yaitu program fasilitasi peningkatan kelompok tani hutan (KTH) pada tahun 2017 dan program fasilitasi pembentukan Wanawiyata Widyakarya tahun 2018. Bantuan yang diterima kelompok tani hutan Lima Bersaudara adalah bantuan dana yang diterima dari Dinas Kehutanan yaitu berupa uang sejumlah Rp 25.000.000,- yang digunakan untuk membeli sarana produksi. Selain itu, kelompok tani hutan Wana Lestari 2 juga mendapatkan dana bantuan dari Bank Indonesia berupa kandang lebah madu berjumlah 4 kotak stup, papan nama kelompok dan kotak etalase.

2. Menjalin hubungan kemitraan

Menurut hasil wawancara dilapangan, KTH Lima Bersaudara menjalin hubungan kemitraan dengan pihak luar. Hubungan kemitraan yang dilakukan adalah kemitraan dalam bidang penampungan hasil madu, kemitraan bidang budidaya dan kemitraan bidang pemasaran. Untuk kemitraan penampungan hasil madu adalah peternak-peternak menjual hasil produksi madu mereka pada kelompok tani hutan Lima Bersaudara, karena peternak-peternak ini belum mampu menjual produk madunya sendiri. Peternak yang biasanya menjual hasil madunya pada KTH Lima Bersaudara adalah peternak dari Buntok, Sampit, Sebangau, Kapuas dan Basarang. Harga beli produk madu dari mitra adalah Rp 60.000,- sampai Rp $100.000,-/ \mathrm{kg}$ tergantung kualitas madu yang dihasilkan. Untuk kemitraan budidaya adalah bentuk kemitraan yang dilakukan dengan cara Bapak Budiyana memberikan pelatihan dan menyediakan bibit untuk peternak pemula yang ingin melakukan usaha budidaya lebah madu. Sedangkan untuk kemitraan pemasaran adalah bentuk kemitraan yang dilakukan 
dengan tujuan pemasaran produk madu. Bapak Budiyana menjalin hubungan kemitraan pemasaran dengan Hypermart, KPD Swalayan dan toko obat Gayuh Husada.

3. Perkembangan teknologi dan informasi

Seiring perkembangan zaman perkembangan teknologi informasi dapat memudahkan peternak untuk beraktifitas melihat berita dan mencari berbagai informasi yang beredar di dunia maya yang berkaitan dengan budidaya lebah madu ataupun teknologi terbaru tentang budidaya lebah madu. Perkembangan teknologi dan informasi yang bisa dimanfaatkan oleh peternak lebah madu di Kalampangan salah satunya adalah penggunaan internet untuk mempromosikan hasil produk madunya untuk konsumen yang berada di Kalimantan Tengah dan diluar Kalimantan Tengah. Untuk KTH Lima Bersaudara, mereka melakukan kegiatan promosi untuk produk lebah madu lewat aplikasi internet seperti Facebook, WhatsApp dan Online Shop. Selain itu untuk KTH Wana Lestari 2, jika mereka memiliki kelebihan produksi madunya mereka biasanya menjual produk madu tersebut melalui internet seperti Facebook.

\section{Ancaman (Threats)}

1. Harga produk madu bersaing

Harga produk madu dari peternak di Kelurahan Kalampangan lebih mahal jika dibandingkan dengan harga produk madu olahan pabrik seperti Madu TJ dan Madurasa. Di Hypermart, harga produk madu dari peternak di Kelurahan Kalampangan untuk ukuran $250 \mathrm{ml}$ dijual dengan harga Rp 131.300,- dan ukuran 500 ml dijual dengan harga Rp 193.800,-. Sedangkan untuk harga Madu TJ ukuran 150 gr $(107 \mathrm{ml})$ dijual dengan harga $\mathrm{Rp}$ 60.650,- dan ukuran $650 \mathrm{ml}$ dijual dengan harga Rp 138.090,-. Di KPD Swalayan, harga produk madu dari peternak di Kelurahan Kalampangan untuk ukuran 100 $\mathrm{ml}$ dijual dengan harga $\mathrm{Rp} 50.000$,- dan ukuran $250 \mathrm{ml}$ dijual dengan harga $\mathrm{Rp}$ 100.000,-. Sementara untuk harga
Madurasa ukuran 150 gr $(107 \mathrm{ml})$ dijual dengan harga $\mathrm{Rp} 20.000$,- dan ukuran 350 gr $(250 \mathrm{ml})$ dijual dengan harga $\mathrm{Rp}$ 45.000,-. Di Toko Obat Gayuh Husada produk madu dari peternak di Kelurahan Kalampangan untuk ukuran $100 \mathrm{ml}$ dijual dengan harga $\mathrm{Rp} 70.000$,-, ukuran $250 \mathrm{ml}$ dijual dengan harga $\mathrm{Rp} 120.000,-$ dan ukuran $500 \mathrm{ml}$ dijual dengan harga $\mathrm{Rp}$ 210.000,-. Sedangkan untuk harga Madu TJ ukuran 150 gr $(107 \mathrm{ml})$ dijual dengan harga Rp 18.000,- dan ukuran 500 gr (350 ml) dijual dengan harga $\mathrm{Rp} 48.000,-$.

2. Perubahan cuaca

Cuaca adalah hal yang sangat penting dalam menunjang usaha budidaya lebah madu di Kalampangan. Perubahan cuaca dapat mempengaruhi hasil produksi madu serta kualitas madu tersebut. Hal ini dikarenakan jika udara panas biasanya lebah madu lebih agresif dibandingkan biasanya, sehingga peternak mengalami kesusahan dalam tahap pembuatan lebah ratu, pemecahan dan penggabungan koloni lebah madu. Akan tetapi jika musim hujan terus menerus, maka lebah akan lebih sering berdiam didalam kotak dan tidak bisa mencari makan. Hal ini mengakibatkan produksi madu menjadi berkurang. Selain musim hujan, perubahan cuaca lain seperti kebakaran hutan yang sering terjadi menyebabkan kabut asap yang cukup lama dan akan menimbulkan kematian pada lebah madu karena lebah madu terpapar asap kebakaran hutan dalam jangka waktu yang cukup lama.

3. Serangan hama

Bentuk hama yang biasanya menyerang budidaya lebah madu di Kelurahan Kalampangan, yaitu burung Raja Udang, naning atau tawon liar dan semut. Burung Raja Udang biasanya memakan lebah madu yang sedang terbang mencari pakan. Naning atau tawon liar biasanya menyerang koloni lebah madu, sehingga koloni lebah madu menjadi terganggu. Sedangkan untuk hama semut yang biasa menyerang sarang lebah madu karena semut menyukai sesuatu yang manis, hal ini mengakibatkan terjadinya 
persaingan makanan dan madu yang terdapat dalam koloni akan berkurang. Selain hama, yang menjadi ancaman pada kegiatan budidaya lebah madu di Kalampangan, ancaman lainnya adalah penggunaan pestisida yang berlebihan disekitar tempat budidaya yang dapat menimbulkan kematian pada lebah madu karena lebah madu menghisap nektar yang mengandung pestisida. Hal ini mengakibatkan lebah madu terlihat tidak bertenaga, tidak mampu terbang dan beberapa jam kemudian lebah madu tersebut akan mati sendiri.

\section{Alternatif Strategi Pengembangan Budidaya Lebah Madu di Kelurahan Kalampangan}

Setelah mengidentifikasi faktorfaktor internal dan eksternal yang menjadi kekuatan, kelemahan, peluang dan ancaman dalam budidaya lebah madu di Kelurahan Kalampangan, Kecamatan Sabangau, Kota Palangka Raya, maka dengan menggunakan analisis matriks SWOT diperoleh beberapa alternatif yang dapat dipertimbangkan guna pengembangan budidaya lebah madu

Tabel 3. Penentuan Strategi dengan Matrik SWOT

\begin{tabular}{|c|c|c|}
\hline & Strength $(S)$ & Weakness $(W)$ \\
\hline EFAS & $\begin{array}{l}\text { 1. Tenaga kerja mengikuti } \\
\text { pelatihan } \\
\text { 2. Ketersediaan sarana } \\
\text { produksi } \\
\text { 3. Manajemen budidaya } \\
\text { telah diterapkan } \\
\text { 4. Rantai pemasaran } \\
\text { pendek }\end{array}$ & $\begin{array}{l}\text { 1. Kurangnya } \\
\text { keikutsertaan anggota } \\
\text { kelompok } \\
\text { 2. Kemasan produk yang } \\
\text { sederhana }\end{array}$ \\
\hline Opportunities $(O)$ & Strategi S-O & Strategi W-O \\
\hline $\begin{array}{l}\text { 1. Adanya perhatian } \\
\text { pemerintah } \\
\text { 2. Menjalin hubungan } \\
\text { kemitraan } \\
\text { 3. Perkembangan } \\
\text { teknologi dan informasi }\end{array}$ & 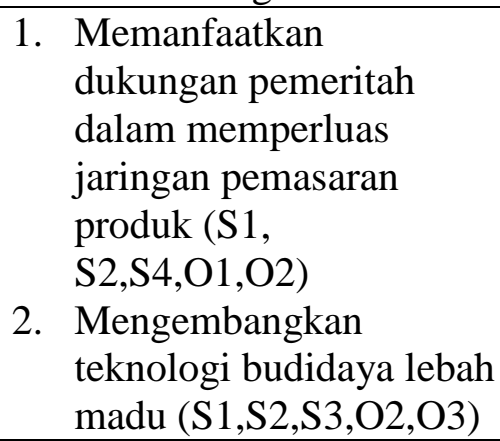 & 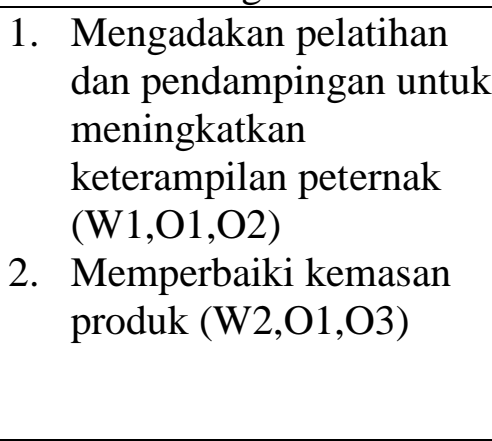 \\
\hline Threats $(T)$ & Strategi S-T & Strategi W-T \\
\hline $\begin{array}{l}\text { 1. Harga produk madu } \\
\text { bersaing } \\
\text { 2. Perubahan cuaca } \\
\text { 3. Serangan hama }\end{array}$ & $\begin{array}{ll}\text { 1. } & \text { Mempertahankan } \\
\text { produksi }(\mathrm{S} 1, \mathrm{~S} 3, \mathrm{~T} 2) \\
\text { 2. } & \text { Menjaga kualitas produk } \\
& (\mathrm{S} 2, \mathrm{~S} 4, \mathrm{~T} 1, \mathrm{~T} 3)\end{array}$ & $\begin{array}{l}\text { 1. Meningkatkan kerja } \\
\text { sama kelompok dan } \\
\text { mempertahankan luasan } \\
\text { areal tanaman pakan } \\
(\mathrm{W} 1, \mathrm{~W} 2, \mathrm{~T} 1, \mathrm{~T} 2, \mathrm{~T} 3)\end{array}$ \\
\hline
\end{tabular}

Sumber: Data primer diolah, 2019.

Berdasarkan analisis matriks SWOT, maka alternatif strategi yang diperoleh adalah, sebagai berikut: Strategi S-O

\begin{tabular}{l}
\multicolumn{1}{c}{ Strategi } \\
$\begin{array}{l}\text { Opportunity) atau } \\
\text { peluang, yaitu: }\end{array}$
\end{tabular}


2. Mengembangkan teknologi budidaya lebah madu.

Strategi W-O

Strategi W-O (Weaknesses-

Opportunity) atau kelemahan-peluang:

1. Mengadakan pelatihan dan pendampingan untuk meningkatkan keterampilan peternak.

2. Memperbaiki kemasan produk.

Strategi S-T

Strategi S-T (Strength-Threat) atau strategi kekuatan-ancaman, yaitu:

1. Mempertahankan produksi.

2. Menjaga kualitas produk.

Strategi W-T

Strategi W-T (Weakness-Threat) atau strategi kelemahan-ancaman, yaitu:

1. Mempertahankan kerja sama kelompok dan menjaga luasan areal tanaman pakan.

\section{KESIMPULAN DAN SARAN}

\section{Kesimpulan}

1. Faktor-faktor internal (kekuatan dan kelemahan) dan eksternal (peluang dan ancaman) pengembangan budidaya lebah madu di Kelurahan Kalampangan yaitu kekuatan memiliki empat variabel antara lain tenaga kerja mengikuti pelatihan, ketersediaan sarana produksi, manajemen budidaya telah diterapkan dan rantai pemasaran pendek. Kelemahan memiliki dua variabel, antara lain kurangnya keikutsertaan anggota kelompok dan kemasan produk yang sederhana. Peluang memiliki tiga variabel, yaitu adanya perhatian pemerintah, menjalin hubungan kemitraan dan perkembangan teknologi dan informasi. Sedangkan ancaman memiliki tiga variabel, antara lain harga produk madu bersaing, perubahan cuaca dan serangan hama.

2. Analisis strategi melalui matriks SWOT menghasilkan tujuh alternatif strategi. Alternatif strategi yang dapat diterapkan dalam upaya pengembangan budidaya lebah madu di Kelurahan
Kalampangan adalah strategi (SO) yaitu memanfaatkan dukungan pemeritah dalam memperluas jaringan pemasaran produk, dan mengembangkan teknologi budidaya lebah madu; strategi (WO) yaitu mengadakan pelatihan dan pendampingan untuk meningkatkan keterampilan peternak dan memperbaiki kemasan produk; strategi (ST) yaitu mempertahankan produksi dan menjaga kualitas produk; strategi (WT) yaitu mempertahankan kerja sama kelompok dan menjaga luasan areal tanaman pakan.

\section{Saran}

1. Kepada peternak lebah madu untuk lebih meningkatkan produk madu yang dipasarkan dengan cara memperbaiki kemasan dan membuat merk dagang sendiri yang bertujuan untuk memberikan nilai berbeda dari produk madu serupa sehingga dapat meningkatkan daya tarik konsumen untuk membeli produk madu tersebut. Selain itu peternak harus menjaga kualitas madu yang dihasilkan dengan cara menanam tanaman yang dapat berbunga sepanjang tahun disekitar tempat budidaya.

2. Kepada pemerintah daerah dapat membantu meningkatkan keterampilan peternak dengan cara mengadakan pelatihan dan pengembangan dalam bidang teknologi budidaya lebah madu. Selain itu pemerintah juga dapat membantu peternak dalam memasarkan produk madu melalui kegiatan pameran dan pembuatan website untuk penjualan online.

\section{DAFTAR PUSTAKA}

Basia, L., Suprihanto, J. \& Armawi, A. (2016). Strategi Pengembangan Wirausaha Pemuda Dalam Mewujudkan Wirausaha Mandiri dan Implikasinya Terhadap 
Ketahanan Ekonomi Keluarga.

Yogyakarta.

Hico. (2016). Cara Budidaya Lebah Madu

Lengkap Untuk Pemula.

https://goodminds.id/budidaya-

lebah-madu/. Diakses 05 September 2018.

Kuntadi. (2010). Pengembangan Budidaya Lebah Madu dan Permasalahannya.

Pusat Penelitian dan Pengembangan Konservasi dan Rehabilitasi, Badan Penelitian dan Pengembangan Kehutanan. Bogor.

Rangkuti, F. (2016). Analisis SWOT Teknik Membedah Kasus Bisnis. Jakarta: Gramedia Pustaka Utama.

Setiawan. (2011). Analisis Kinerja Perusahaan Dodol Olimpic Garut Dengan Balance Scored. Skripsi. Sekolah Tinggi Teknologi Garut. Garut.

Sugiyono. (2005). Statistika Untuk Penelitian. Bandung: CV Alfabeta. (2013). Metode Penelitian Kuantitatif Kualitatif dan R \& G. Bandung: CV Alfabeta. 